\title{
EUTOMIA
}

Revista de Literatura e Linguística

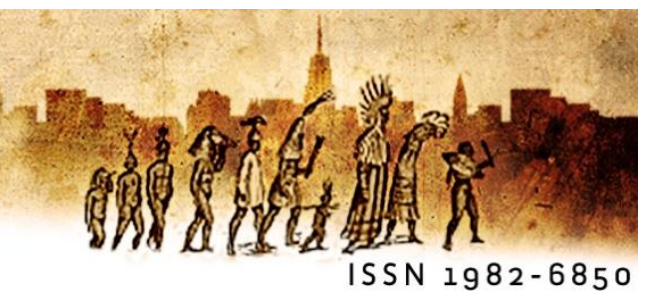

\section{Amor e política, uma comunidade do dano: condições precárias em alguma poesia brasileira contemporânea escrita por mulheres.}

\author{
Love and politics, a damage community: \\ precarious conditions in some contemporary \\ Brazilian poetry written by women.
}

Danielle Magalhães' (UFRJ)

\begin{abstract}
Resumo: Uma das tendências da poesia brasileira contemporânea é a grande presença de poetas mulheres e um dos pontos em comum que une parte dessa produção escrita por mulheres é a condição precária que se determina em vários fatores, como o gênero e a pobreza, por exemplo. Muitas poetas expõem a misoginia, o machismo, o feminicídio, o racismo, a normatividade de gênero e a pobreza em uma abordagem que entrelaça amor e política. Afinando-se com a noção de "precariedade" de Judith Butler, esse artigo pretende mostrar algumas condições de precariedade que fazem dessas poetas uma comunidade pautada no dano, aproximando-se em uma luta lá onde elas aparentemente não se aproximariam. Serão abordadas as poetas Tatiana Nascimento e Tatiana Pequeno.
\end{abstract}

Palavras-chave: Mulheres; Precariedade; Amor; Política.

Abstract: One of the trends of contemporary Brazilian poetry is the great presence of female poets and one of the common points that unites part of this production written by women is the precarious condition that is determined by several factors, such as gender and poverty, for example. Many poets expose misogyny, machismo, feminicide, racism, gender normativity and poverty in an approach that intertwines love and politics. In tune with Judith Butler's notion of "precariousness", this article intends to show some precarious conditions that make these poets a community based on harm, approaching in a struggle where they apparently would not approach. The poets Tatiana Nascimento and Tatiana Pequeno will 
be addressed. The poets that are studied are Tatiana Nascimento e Tatiana Pequeno.

Keywords: Women; Precariousness; Love; Politics.

Nunca antes na história desse país houve uma produção tão grande de poesia escrita por mulheres. No livro Explosão Feminista, Julia Klien e Heloísa Buarque de Hollanda atestam esse fenômeno: "De 2010 para cá, intimamente ligada às recentes manifestações feministas, uma nova poesia escrita por mulheres, lésbicas e trans ganha força inesperada e se amplifica com rapidez" (HOLLANDA, 2018, s/p). Além disso, destaca-se a indissociabilidade do político e do poético, como elas dizem, a "indissociabilidade dos seus posicionamentos políticos e da sua linguagem poética é um caso emblemático na poesia brasileira recente" (HOLLANDA, 2018, s/p). Em alguns exemplos, podemos ver como as condições de precariedade a que corpos de mulheres, mulheres pobres, mulheres negras, mulheres LGBTOI+, dizem completamente respeito ao modo como se ama e como esse modo está indissociável do posicionamento político. O poema da poeta, editora, professora, tradutora, cantora e compositora brasiliense Tatiana Nascimento, presente no livro o7 notas sobre o apocalipse ou poemas para o fim do mundo, na seção "o7 notas sobre o apocalipse, ou, daria um poema esqueersito, essa revolução", intitulado "cuíer A.P. (ou "oriki de shiva", v. 28 out. 2018$)^{\prime \prime}$, diz:

nós vamos destruir tudo aquilo que você ama e tudo que vc chama "amor" a gente vai destruir

porque c chama "amor à pátria"

o que é racismo

c chama "amor a deus"

o que é fundamentalismo

c chama "amor pela família"

o que é sexismo homofóbico y

c chama transfobia de "amor à natureza"

(o que que c sabe da natureza? pra vc a natureza

é só mais alguém pra ser dominada)

o q c chama de "amor pela segurança"

é militarismo

y o capitalismo

c chama de "amor pelo trabalho"

(mas mentira, é pura adoração pelo dinheiro) 


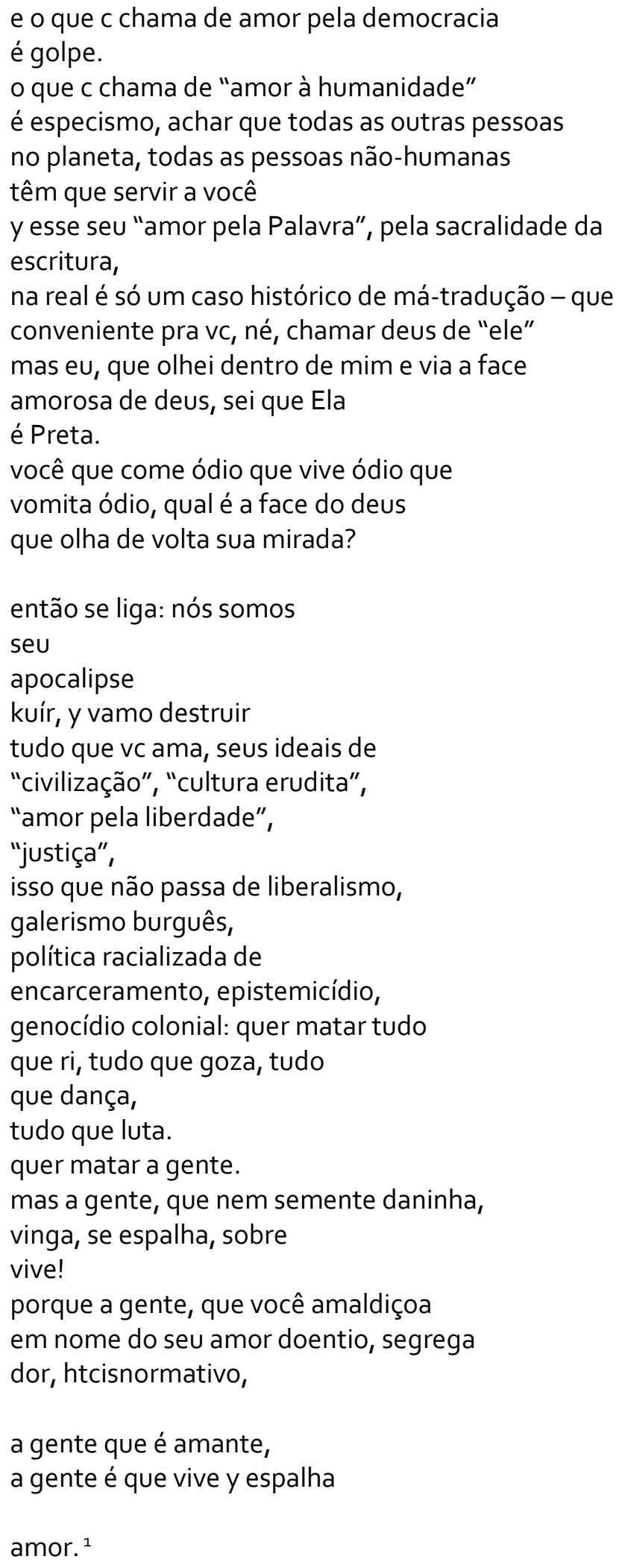

\footnotetext{
1 No livro, o último verso, "amor", aparece sozinho na página 12. Há um longo espaçamento, praticamente de uma página, entre o verso "a gente é que vive y espalha", que está na página 11, e o último verso, "amor", que está na página 12. Na impossibilidade de manter esse espaçamento na citação, recorro a fotografias dessas páginas do poema tal como ele se apresenta no livro:
} 
(NASCIMENTO, 2019a, p. 11-12)

No poema de Tatiana Nascimento, afirmar que "nós somos/ seu/ apocalipse" é dizer que nós somos o seu fim do mundo não porque vamos lhe matar, mas porque a afirmação do nosso modo de amar nega o seu horror travestido de amor, porque o seu modo de amar nos aniquila e aniquila o nosso modo de amar ("quer matar tudo/ que ri, tudo que goza, tudo/ que dança,/ tudo que luta./ quer matar a gente"). Dizer "nós vamos destruir tudo aquilo que você ama" é afirmar que "o seu modo de amar nos aniquila e nós vamos te destruir não porque iremos te matar, mas porque amamos de forma radicalmente oposta a você, porque o seu modo de amar não é amor, é horror": racismo, fundamentalismo, sexismo, homofobia, militarismo, capitalismo, especismo, ódio, liberalismo, espitemicídio, genocídio.

Tatiana Nascimento constrói uma escrita abarcada por gírias ("então se liga"); pela informalidade ("conveniente pra vc, né"); pela linguagem coloquial ("a gente"); pela escrita marcada pelo sotaque ("vamo destruir"); pela escrita tal como a sonoridade da palavra de quando é falada ("cuír" e "kuír"); pelo comparecimento do "cu" que porta o som da palavra queer quando falada; pelo uso do " $y$ " no lugar do "e" aditivo ("o q c chama de "amor pela segurança"/ é militarismo/ y o capitalismo"), interferindo no português com o espanhol, propiciando uma escrita marcada pelo cruzamento latino-americano; por fraturas no interior das próprias palavras, como "segrega/ dor" e "sobre/ vive!", indicando, pelas cesuras, a possibilidade de leitura de duas palavras na mesma, indicando que segregar já porta a dor, e que, dizer sobre o que se espalha por

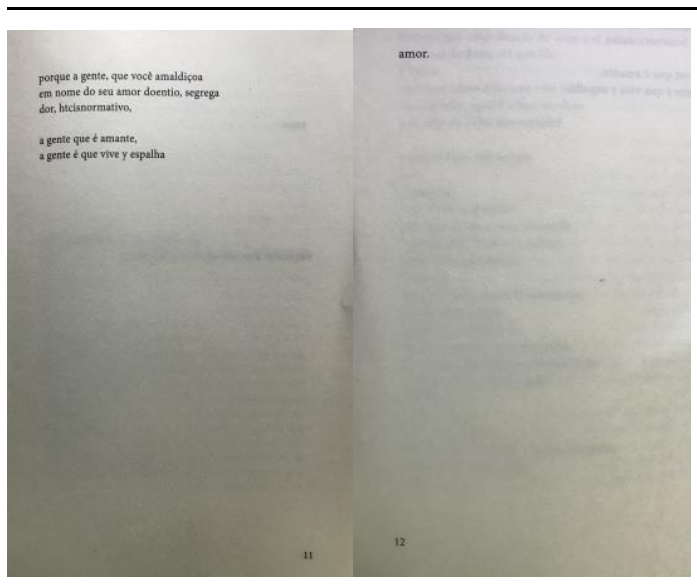


sobre, é dizer do que sobrevive; por contrações e abreviaturas que compõem a linguagem das redes sociais ("htcisnormativo", "vc", "c", "q"), linguagem que certas vezes reduz a palavra à letra, em uma economia radical de um ponto nevrálgico; por uma escrita em que o título já é uma economia da condensação de três palavras em uma, "esquerda", "queer" e "esquisito" em "esqueersito"; por uma escrita em que letra e voz se diferenciam quando o poema é lido no papel e quando é lido em voz alta; enfim, por uma escrita que em sua economia também subverte a norma gramatical, a norma culta gramatical e, em todos os sentidos, a norma (de gênero, do capitalismo, do liberalismo, do fundamentalismo religioso, do colonialismo, do ultraconservadorismo). Como nos dizem Julia Klien e Heloísa Buarque de Hollanda, a "nova onda" de poetas é marcada por uma forte influência da oralidade: "Convivem agora o poema escrito, mais 'literário', com o poema falado, mais abertamente ativista. Essa poesia oral, é importante notar, não vem apenas do impacto do rap, como se poderia presumir, mas também de pesquisas de oralidades regionais" (HOLLANDA, 2018, s/p). Assim, como vemos com o exemplo do poema de Tatiana Nascimento, uma parte da produção poética atual tensiona fortemente o escrito e o oral, a fala e o corpo, produzindo subjetividades não normativas ao romper com a norma culta da língua.

No poema de Tatiana Nascimento, falar de amor se passa necessariamente pela ruptura da norma da língua, pela ruptura das normas de gênero e por um posicionamento político declarado de esquerda em que esse posicionamento também não se dissocia desse modo de amar. $O$ posicionamento político, então, diz completamente respeito ao modo como se ama. O que está em jogo no poema é uma disputa de narrativa sobre o amor, uma afirmação de uma tradução contra outra, que não desvincula o modo como se ama do posicionamento político.

Em Corpos em aliança e a política das ruas, lemos que, para Judith Butler, a precariedade "designa a situação politicamente induzida na qual determinadas populações sofrem as consequências da deterioração de redes de apoio sociais e econômicas mais do que outras, e ficam diferencialmente expostas ao dano, à violência e à morte" (BUTLER, 2018, p.40). Em outro momento do livro, lemos: 
"uma condição compartilhada de precariedade situa nossa vida política" (BUTLER, 2018, p. 106). Em outro momento, lemos ainda: "A precariedade é a rubrica que une as mulheres, os queers, as pessoas transgêneras, os pobres, aqueles com habilidades diferenciadas, os apátridas, mas também as minorias raciais e religiosas: é uma condição social e econômica, não uma identidade" (BUTLER, 2018, p. 65). Essa marca porta a interdependência, a aliança que se torna o comum de tantas e tantos que, a princípio, não teriam muito em comum.

A título de explicitação deste elo, penso em outro poema de Tatiana Nascimento, publicado no mesmo livro referido, intitulado "manifesta queerlombola, ou tecnologia / ancestral / de cura / amor / y de / prazer" (NASCIMENTO, 2019a, p. 35). Logo de cara, no título, encontramos a junção entre as palavras queer e "quilombola". Mais que uma junção, queer dá em quilombola, queer está em quilombola. As duas palavras juntas já não são exatamente uma adição da luta de gênero com a luta quilombola, da luta de gênero com a luta negra, mas a transformação em outra palavra, a transformação em outro nome, nem queer nem quilombola, mas queerlombola. Esse novo nome já excede a identidade, não diz mais respeito a um, mas é em si uma aliança que, por sua vez, não é uma mera adição, mas a transformação da identidade, a transformação da independência em interdependência. A nova palavra transforma, inclusive, o gênero da primeira: manifesto vira manifesta. Inverte-se a concordância, indecidindo entre substantivo e verbo, transformando o substantivo. Essa "tecnologia", como diz o título, essa máquina de transformação da linguagem, do discurso, da iterabilidade performática, em outro título de outro poema vem associada ao amor: "o amor é uma tecnologia de guerra (cientistas subnotificam arma-biológica) indestrutível" (NASCIMENTO, 2019a, p. 21). Amor que, pelo poema, sabemos que é um amor entre duas mulheres ("é nossa arma de guerra, 'mana minha', desejada// amante" (NASCIMENTO, 2019a, p. 21)). Essa "tecnologia" transgressora em que queer e quilombola se transformam em queerlombola não é senão um engendramento que parte do corpo e do modo como se ama: 


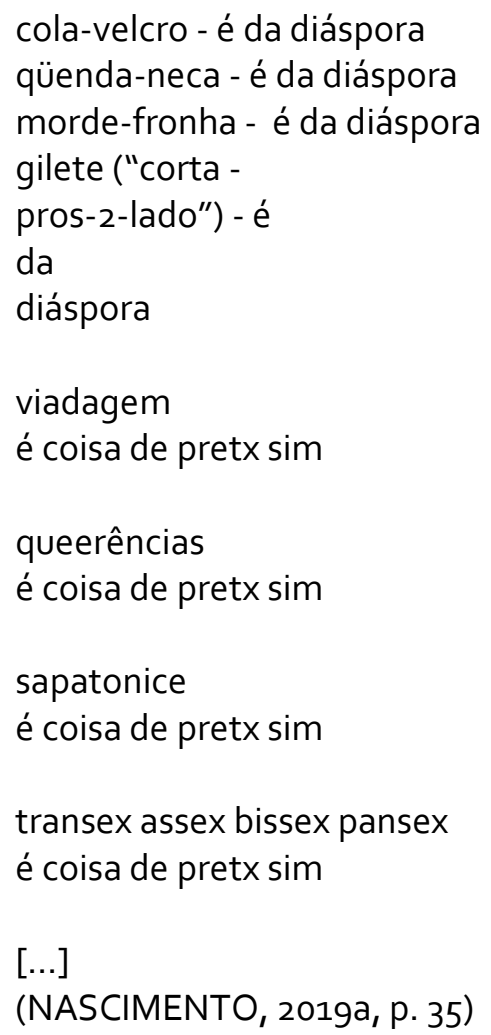

No poema acima, contrapõe-se o que "é da diáspora" ao que "é coisa de pretx sim": enquanto as designações ligadas ao gênero e ao investimento amoroso da primeira estrofe são atreladas à diáspora, ao deslocamento forçado, ao preconceito, portanto, levando a crer que essas designações não são "coisa de pretx", mas do colonizador, as designações dos dísticos ("viadagem", "querências", "sapatonice", "transex assex bissex pansex") são, ao contrário, afirmadas na cor do corpo colonizado, do corpo que sofreu a diáspora. A cor que, a princípio, não teria a ver com as afirmações de gênero, corrobora as afirmações de gênero.

No cordel da série "Pandemia" da n-1 edições, intitulado Cuírlombismo literário, não só encontramos a palavra "aqueerlombamento" riscada, seguida de "acuírlombamento", ("aqueerlombamento acuírlombamento"), como também Tatiana Nascimento explica "a parecença entre queer e quilombo": "a parecença entre queer e quilombo sugere algo urgente a celebrar y a retomar pra nossas lutas e existências, já que os pilares mais rígidos y antigos do racismo colonial são o silenciamento e as expectativas sexuais sobre corpos negros" (NASCIMENTO, 2019b, p. 4, grifos da autora). Nesse livro, também se afirma o 
modo como se diz a palavra no poema anterior, "Apocalipse cuír", com "cu", forjando o conceito de "cuírlombismo". Essa invenção, Tatiana Nascimento explica, vem de uma junção de Nascimentos, precisamente, de dois Nascimentos: a conceituação de Beatriz Nascimento, que diz que "mais que 'grupos de escravos fugidos', eles [os quilombos] formam experimentações de liberdade" (NASCIMENTO, B. apud NASCIMENTO, T., 2019b, p. 16), com o programa de outro Nascimento, o grande intelectual e ativista negro Abdias do Nascimento, que compreende o quilombismo como "'um movimento político dos negros brasileiros, objetivando a implantação de um Estado Nacional Quilombista, inspirado na República dos Palmares"' (NASCIMENTO, A. apud NASCIMENTO, T., 2019b, p. 15). Nas palavras de Tatiana: "conectando a conceituação pioneira de nascimento b. ao projeto de nascimento a., forjo desde meu lugar afrodiaspórico sexual-dissidente o conceito de cuírlombismo literário (nascimento t.)" (NASCIMENTO, 2019b, p. 18).

Em Corpos em aliança, Butler pensa que o que une a condição das pessoas oprimidas e violentadas pela normatividade de gênero, em seu pensamento sobre teoria queer, ao qual ela se dedicou ao longo de todo seu trabalho, com a condição de outra parcela de pessoas oprimidas e violentadas, é a precariedade, é a vida não digna de ser vivida a qual estão submetidas:

Em Problemas de gênero (1989), algumas vezes parecia que certos atos que os indivíduos podiam executar tinham ou podiam ter um efeito subversivo sobre as normas de gênero. Agora eu estou trabalhando a questão das alianças entre várias minorias ou populações consideradas descartáveis; mais especificamente, estou preocupada com a maneira pela qual a precariedade - esse termo médio e, de algumas formas, esse termo mediador - pode operar, ou está operando, como um lugar de aliança entre grupos de pessoas que de outro modo não teriam muito em comum e entre os quais algumas vezes existe até mesmo desconfiança e antagonismo (BUTLER, 2018, p. 34).

Operando a partir da "precariedade" como um "termo mediador", a filósofa estadunidense não só traz o corpo para o centro da política e como questão política, mas é ainda pela noção de um "corpo em risco", de corpos em 
que o aparecimento ou a exposição já significa um risco, como um corpo de um manifestante frente à polícia, como um corpo negro frente à polícia, como um corpo pobre frente à polícia, como um corpo de uma mulher que anda na rua, como os corpos de gays, lésbicas e todos os corpos que se abrem na sigla LBGTQI+, que Butler instaura um pensamento em que pensar o corpo como centro e questão da política é mais que pensar o corpo, é pensar um corpo em risco. E esse pensamento não se faz senão ele mesmo como uma aliança: nele, pensar a teoria da performatividade de gênero é pensar, entrelaçadamente, uma amplidão de vidas que, pela precariedade, são determinadas como descartáveis. Unindo performatividade e precariedade, Butler vai às minorias sexuais no ponto em que as liga com as populações precárias: a condição de serem matáveis, descartáveis ou vidas "não passíveis de luto" (BUTLER, 2018, p. 34). Se é a precariedade que situa a nossa vida política, como disse a teórica, se a precariedade é o fator que nos localiza em um comum que partilhamos, Butler inverte o princípio mesmo pelo qual a política é pensada desde os primórdios. Pensar a política é então pensá-la pelo ponto que, desde os seus fundamentos ocidentais, era considerado o oposto da política desde Aristóteles: a sobrevivência, a necessidade, a precariedade, a vida submetida ao corpo.

Se, em Tatiana Nascimento, a luta de gênero está aliada à luta negra (que vem tanto pelo corpo, pela cor, quanto pelo espaço de luta dos escravos, os quilombos, sendo, portanto, uma luta que passa pelo corpo, pela religiosidade ancestral africana e pelo quilombo enquanto espaço territorial e simbólico de organização, criação, resistência e luta) e ambas operam pelo amor, em Tatiana Pequeno, por exemplo, o amor aparece diretamente relacionado com a luta das mulheres e dos/das desfavorecidos economicamente, dos/das excluídos pela desigualdade econômico-social. Na mesma abordagem, fala-se de um relacionamento e das formas variadas de miséria da lógica sinistra que rege o capitalismo, fazendo do íntimo, do privado, da casa, do amor, uma passagem para o público, para a política. Assim lemos no seguinte poema: 
acordei na madrugada, amor, e havia tiros que circulavam atrás da nossa janela sombreando a mandala da colcha que resolvemos usar como cortina.

faz barulho lá fora e em breve você acorda no sentido santa cruz e eu permaneço aqui, atenta e

ouvinte da fisiologia dos gatos

compreendendo a lógica feroz dos

nossos vizinhos e celebrando minhas pequenas vitórias de

testemunha

viva do que todos os dias permanece

sendo a vida incompreensível.

já já amanhece, amor, e eu vou

vendo no tempo meu espelho

descobrindo um outro cabelo branco

ou um desgaste obstinado da pintura

perto da parede que há um ano era lisa.

os tiros não param.

não vou mais fazer aquela pergunta

sobre o tempo porque a adriana calcanhotto disse que não

interessava

a visão política dos poetas então

eu fico aqui insone neste bairro da zona norte ouvindo rajadas das

muitas vidas separadas do

morro da outra rua eu penso nas crianças lá em cima no

morro dos macacos eu penso que

a minha profissão é uma utopia

eu penso que gostaria de dividir com você um mundo justo (eu prometi a mim mesma que escreveria este poema sem a palavra mundo ou tempo mas eu falhei, me desculpem os poetas

que são expertises em tudo em que sou fraca, desculpem os críticos, as [adrianas, amigos ou

irmãos feéricos da poesia)

em que todo fim de mês não precisassem existir brigas em função

das contas ou que sempre

conseguíssemos decorar o que dizer ou fazer para o casal que nos

pede dinheiro na entrada do

supermercado

(o bebê está sempre com remelas)

enfim, amor, como poderíamos bem respirar

diante de tanta disparidade, como conseguimos comer peixe

sabendo que há os tiros e

as crianças e o casal

como eu posso dormir se a minha beleza fraqueja diante dessa

inaptidão dos poetas?

uma vez eu te disse, amor, tuas mãos são saúde e as

minhas têm uma espécie de maldição

que é dedilhar o caos, saber o relevo e o tamanho da crosta das

cascas que é olhar a mandala e

só ver os tiros, amor, você e essa palavra que preciso repetir para não

adoecer, amor, os tiros, as

Eutomia, Recife, 26(1): 211-234, Dez. 2020 
crianças, teu sono cansado, as fissuras, a tarde imensa da minha solidão, o som dos tiros

invadindo a nossa cama, o passado a meu lado, minha memória nem amanhece e o que há é a guarita do teu sono pesando firme o desejo de outra madrugada com menos tiros tão próximos de nós, amor, outro tempo, outro mundo, outra forma de traduzir a falência que brilha na remela da criança, vou repetir o vocativo que me sugeriram retirar da poesia, amor outro tempo, outro mundo para nós.

A carta ou o poema acima, de Tatiana Pequeno, é, até agora, inédito em livro. Ele foi publicado na Revista Gueto² dias depois do primeiro lançamento do livro Onde estão as bombas, pela editora Macondo, no Rio de Janeiro, em julho de 2019. Nesse poema, o título se confunde com o destinatário e o endereçamento a ele. O título é a destinatária. No começo, a destinação, a dedicação, a dedicatória. No começo, o amor: "acordei na madrugada, amor". Mas, também no começo, no mesmo e primeiro verso, o horror: "acordei na madrugada, amor, e havia tiros que circulavam atrás da nossa janela". Desde o título, esse poema poderia ser uma carta de amor. Há uma enunciação sempre amorosa: "já já amanhece, amor". Esse vocativo, "amor", comparece ao longo do poema: "enfim, amor"; "uma vez eu te disse, amor". Escrever para a pessoa amada enquanto a pessoa dorme. Escrever para a pessoa amada o que se passa enquanto a pessoa amada dorme ao lado de quem escreve. Mas essa carta de amor extrapola a intimidade, ela não se reduz à intimidade. Nela, há prenúncio de morte e celebração. Mas o que se celebra não é exatamente a vida em si em oposição à morte, é o fato de ser "testemunha/ viva do que todos os dias permanece/ sendo a vida incompreensível". Esse poema-carta-de-amor é, desde então, testemunho, testemunho do que permanece na incompreensibilidade da vida. O que se passa, entre tiros, enquanto a pessoa amada dorme ao lado de quem escreve, em vigília, insone?

\footnotetext{
2 Disponivel em https://revistagueto.com/2019/07/29/cinco-poemas-detatianapequeno/?fbclid=IwAR2FtjMIDrOAErzAP3mYvakegIrf26p4wM458ChlcouMT92vn74FiMw 4 r4 Acesso em 03/03/2020.
} 
O ato da escrita acontece entre tiros, o tempo da escrita acontece entre tiros, o poema-carta-de-amor é escrito entre tiros. Entre tiros, a "fisiologia dos gatos" desliza para "a lógica feroz dos vizinhos", o "cabelo branco" que indica a passagem do tempo ou desgaste da pintura da parede do quarto ("descobrindo um outro cabelo branco/ ou um desgaste obstinado da pintura/ perto da parede que há um ano era lisa") desliza para o tempo-agora em que a cantora famosa separa poesia e política. ${ }^{3} \mathrm{O}$ que se dá entre esses dois tempos são os tiros: "os tiros não param" é o verso que separa um tempo do outro, uma cena da outra. Entre tiros, um poema, uma carta de amor, uma carta aos críticos, uma autocrítica ou um eu que se pensa (irônica e não ironicamente), uma carta aos poetas, uma carta ao ofício, uma carta ao nosso tempo, um desejo de um tempo outro, um testemunho.

A crítica a uma certa crítica desliza para o lugar em que se está, o pensamento sobre o lugar de ofício desliza para a constatação do lugar fronteiriço em que se está geograficamente em relação aos tiros, embaixo, em um quarto em um bairro da Zona Norte do Rio de Janeiro, distante e perto do morro "lá em cima". Como testemunho, o poema se escreve na falha, na rasura, terminando com as palavras "mundo" e "tempo", quebrando a promessa inicial: "(eu prometi a mim mesma que escreveria este poema sem a palavra mundo ou tempo mas eu falhei, me desculpem os poetas/ que são expertises em tudo em que sou fraca, desculpem os críticos, as adrianas, amigos ou/ irmãos feéricos da poesia)". Mostrando que quem escreve é a falha, no fim inscrevem-se "tempo" e "mundo" na rasura da promessa de não escrever "tempo" e "mundo": "amor, outro tempo, outro mundo,/ outra forma de traduzir a falência/ que brilha na remela da criança,/ vou repetir o vocativo que me/ sugeriram retirar da poesia, amor/ outro tempo, outro mundo/ para nós". Ao inscrever "tempo" e "mundo" na rasura, na quebra, na falha da promessa, o que se inscreve não é senão outra palavra, que também é outra crítica à crítica: ao inscrever "tempo" e "mundo",

\footnotetext{
3 Adriana Calcanhoto organizou a antologia intitulada É agora como nunca: antologia incompleta da poesia contemporânea brasileira, publicada pela Companhia das Letras em 2017. Em entrevista ao Suplemento Pernambuco, sobre a antologia, ela disse: "não me interessa visão política dos poetas". A entrevista está disponível aqui: https://suplementopernambuco.com.br/entrevistas/1802-n\%C $3 \% \mathrm{~A}_{3} 0$-estou-interessada-na posi\% $3 \% \mathrm{C}_{3} \% \mathrm{C}_{3} \% \mathrm{~A}_{3}$-pol\%C3\%ADtica-dos-poetas.html Acesso em 03/03/2020.
} 
inscreve-se "amor", rasurando a crítica, escrevendo em cima dessa, riscando-a, borrando-a, inscrevendo-se, novamente, ao traçar as palavras "tempo", "mundo" e "amor", um pensamento sobre a poesia.

Cruzam-se, no poema, uma carta de amor, um pensamento sobre a profissão, sobre o ofício de poeta, sobre a poesia, sobre a crítica, sobre o mundo, sobre o tempo, de modo que a vida íntima de casal leva a pensar no casal que pede dinheiro na entrada do supermercado, a briga pelas contas na vida pessoal desliza para a pobreza intransponível, as contas a serem pagas deslizam para a miséria. As perguntas deslizam para uma resposta que não se decora. Aliás, as perguntas feitas são dirigidas ao "amor", que comparece em seu adormecimento e que não dá repostas. O poema também é uma carta não só de amor, mas ao amor. As perguntas feitas são dirigidas ao amor, assim como escrever na vigília é escrever ao despertar. O que se passa, entre tiros, falando ao amor, enquanto ele adormece, é a vigília que cruza o pessoal e o coletivo, o lugar em que se está em casa e no mundo. O poema é um desejo de partilha, de dividir, de colocar junto, de colocar em relação, justaposto, o que está separado, como o débito da poesia e as contas do casal, como a falha da poeta e as fissuras entre os tempos e os mundos, como as brigas de casal por causa das contas e o casal na rua que pede dinheiro na entrada do supermercado, como o quarto embaixo e as crianças "lá em cima" no morro, como o desenho da mandala e o do traçante dos tiros, como o sentido por onde se encaminha certa crítica e o "sentido santa cruz" (para onde vai o amor quando acorda: "em breve você acorda no sentido santa cruz"), como a beleza das expertises da poesia e a remela do bebê, como o amor e o horror, essas disparidades ("enfim, amor, como poderíamos bem respirar/ diante de tanta disparidade").

Em Onde estão as bombas, o existir das cartas, das destinações explicitadas enquanto envios, denominadas ou não, é uma constante. Dentre outras, há uma "carta para alguém depois dos protestos", em que a quentura e a densidade da noite que "ferve" e "arde sulfurada" "das cavalarias/ de choque e da pimenta azeda" contrastam com o vazio e com os restos. Nesse poema que, em algum grau, como o anterior, é uma carta e um testemunho, o início da história do Rio de Janeiro e do Brasil é atualizado no presente, a Praça XV, 
primeiro porto da cidade, é atualizada nas cavalarias de choque, as especiarias são atualizadas no spray de pimenta ("é quente a noite no rio e a praça xv/ arde sulfurada pelo estranho torpor/ dos normais depois das cavalarias/ de choque e da pimenta azeda que/ trouxeram nos barcos dos pinheiros/ sal vinagre especiarias azeviche" (PEQUENO, 2019, p. 42)), a colonização é atualizada nas demissões ("agora ferve a noite no rio e o centro/ está vazio como se os habitantes / todos tivessem sido demitidos" (PEQUENO, 2019, p. 42)). Entre o centro e o subúrbio, o protesto e o silêncio, a marcha e o amortecimento, palavras e nenhuma escuta: "não há pequenina luz nenhuma a/ penas um homem em farrapos/ que diz ter uma palavra importante/ a ser compartilhada embora/ ninguém aqui possa ouvi-lo" (PEOUENO, 2019, p. 42).

Em Aceno, outro livro da poeta, encontramos outra carta "depois dos protestos", cujo destinatário é nomeado. Se o endereçamento a "alguém" é também um endereçamento aos "protestos", já que falar "depois dos protestos" é falar desde os protestos, nesta próxima carta, o endereçamento amoroso é também um endereçamento desde os protestos, de modo que se endereçar ao amor ou à pessoa amada é se endereçar desde a política. Só que, aqui, amor e política estão entrecruzados em um luto:

carta para Mariana, depois dos protestos penso sobre o seu silêncio e escuto agora uma artilharia pesada de gás e de choques como se aguardasse o impossivel gesto que você prometeu nunca me direcionar. guardo a sua face pelo rosto lavado de sal da última despedida e nada do que fomos nos quartos onde sistematicamente nos despe dimos repara os mais de mil quilômetros do litoral que percorro há meses para chegar no movimento central das reivindicações e na marcha correta dos aflitos e dos protestos. os dias têm sido tentativas ignorantes de ver como é sagrada a depredação e os ajustes, mais por você que por mim pois retive da última internação outros monolitos que não posso e não consigo devolver ou simplesmente fazer deslizar rápido pelos néfrons. porque é por meio deles que não amo e não serei capaz de amar outros senão 
vândalos e hereges - tu mesmo esquecida acenando entre bandeiras e táxis a perda dos empregos para os quais não se nasce ou sobre vive. de ti, Mariana, apenas a réstia de imagem depois da revista da guarda a caminho de uma filiação médica (ou militar) em Madureira: algo como uma página escondida sob mãos desfeitas e desenlaçadas num inverno de muito medo e combate.

Rio de Janeiro, 18 de junho de 2013

(PEQUENO, 2014, p. 72-73)

Pensar sobre o silêncio da pessoa amada é escutar um barulho insuportável como "uma artilharia pesada de gás e de choques". Nos lugares onde o amor se deu, "despir" é solapado por "despedir" ("quartos onde sistematicamente nos despe/ dimos"), o lugar onde se dá o encontro amoroso também é o lugar do desenlace. Os cômodos de proximidade e intimidade são lugares que despem, que deixam nu, em cuja nudez está embutida a possibilidade de despedida. Os quartos onde o amor foi encontro e despedida não reparam a distância quilométrica para chegar ao movimento público. Os quartos não reparam o efeito imoral das bombas de efeito moral que assolam as ruas do Rio de Janeiro de 2013 até hoje. No poema, há deslizamento entre despir e despedir, mas não há deslizamento nos monólitos que atravancam os lugares de passagem do corpo. Entrecruzam-se estados de emergência: o corpo exposto à vida nua (o corpo em um hospital), a política (a marcha dos aflitos), e o amor (em despe/dida). Na despedida desnuda do amor, o desnudamento do corpo, a vida em sua nudez de quando o atravessamento dos monólitos se assemelha ao atravessamento de vândalos e hereges: todos como excretas indesejadas. Os monólitos não deslizam por onde, no corpo, é passagem, os néfrons: eles ficam atravessados como excretas indesejadas. A retenção dos monólitos, isso que fica atravessado no corpo, que não desliza, é o meio pelo qual não se ama outros senão "vândalos e hereges", isso que, como os monólitos, se não filtrado, fica atravessado como excreta indesejada. Os monólitos como indicação do que fica atravessado, do que interrompe o fluxo, são a imagem dos vândalos e hereges como isso que também se carrega no 
corpo, e o amor é colocado ao lado desses: "tu mesmo esquecida". O amor é colocado ao lado desses, dos esquecidos, como aquele que acena para a perda, a perda dos empregos. Amor, política, corpo e economia estão em íntima relação, ou, falar de amor é falar de corpo em uma relação política-econômico-social.

Além disso, estar a caminho do "movimento central das reivindicações" é lembrar o caminho do subúrbio, do desencontro amoroso, e fazer restar, como a maior carta amor diante da perda e do desenlace, o caminho de uma filiação da qual não se quer fazer parte. Nesse resto, traz-se, no amor, a linhagem dos desempregados. Destinar uma carta a um amor é destinar uma carta às "mãos desfeitas/ e desenlaçadas", essas que estão sempre marcadas pela nudez do corpo exposto à demissão, à despe/dida. O luto de um amor se mistura com outra dimensão da perda. Aqui, o sentido de perda traz lado a lado a dimensão do trabalho e do luto, duas economias calcadas no dano.

Nessa contagem de danos há, porém, o incalculável que, apesar de andar na superfície, é relegado ao mais subterrâneo que o metrô, porque habita a linha de extinção:

avanço protegida por uma película de vidro - esta janela — por onde filtro cegada pelo sol o bebê caído de uma teta mirrada de mãe verde entrando pelo coletivo e assumindo seu desejo de transbordar tudo o que for falta. queria escutá-la mas havia uma transparência imanente eu a trouxe para cá, todavia queria que ela falasse no meu poema ela pede centavos para não morrer e diz a cerveja poderia me ajudar a parar a cerveja no entanto é muito lenta abro a bolsa constrangida porque aqui sou eu que tenho pele demais aqui sei que estou retornando à casa aqui gaguejo e murmuro ainda constrangida pela visão do bebê absorto pendurado no semelhante peito caído posso te fazer algo a mais e ela diz me dá dinheiro e depois me esqueça muitos dizem sentimos muito e é ver dade que não há nada que possamos fazer 
ressono de culpa, acordo, ela permanece atrás, sentada com

seu bebê atravessado pelo contágio

é uma criança hipotônica recém-saída

da faixa dos conflitos onde se espera a gratuidade dos extermínios

nunca vou esquecer o seu corpo tampouco sua voz de fantasmas e

ausências graves de fumo.

me esqueça - relembro - essa frase

que guardo há meses doendo os dedos

quando conto as moedas quando

retomo o mesmo caminho para os

sonhos ou para casa para a espinha

que fica a me botar de pé entre sorrisos,

salários ou cabelos novos.

vamos te esquecer certamente

eu vou tanto que te guardo aqui neste

poema para lembrar que não podemos

te esquecer porque nós te levamos

às pedras nós transformamos você

também em cinza eu finjo que não

a conheço quando prossigo depois

do sinal fechado e me esforço para

saber onde foi que nos separamos

e em que espelho empobrecido ficou

a tua verdadeira face que diz aqui

é o que me restou dos acidentes.

me esqueça, sei, compreendi mas

é que não posso é que não sei e é

exatamente o que faço todos os dias

não sei e não saber relembra o fim

desta civilização genocida

eles não sabem

os especialistas não sabem

estou e estamos sonâmbulos à nossa revelia.

olho-te inteira e queria que me olhasses

de volta para que tua criança ameaçasse um choro um

escândalo uma antipatia enquanto

tento te esquecer através da minha

poesia já que te dei um nome secreto

e gravito entre o teu silêncio e a minha falta de economia neste longo

poema solitário

perdoa-nos a pele, perdoa a indiferença dos poetas, as notas nos bolsos,

fica.

(PEQUENO, 2019, p. 23-25)

Eutomia, Recife, 26(1): 211-234, Dez. 2020 
O poema, que é uma narrativa, que é um "breve ensaio", intitulado "breve ensaio contra a minha indiferença à cracolândia do jacaré", bairro localizado na periferia da Zona Norte do Rio de Janeiro, traça, em oximoros, o que fica interrompido no caminho em que se avança ("avanço protegida por uma película"). No avanço do caminho, "casa" (lugar de destino: "aqui sei que estou retornando à casa") e "coletivo" (lugar em que se está: "avanço protegida por uma película/ de vidro - esta janela - por onde/ filtro cegada pelo sol o bebê caído/ de uma teta mirrada de mãe verde/ entrando pelo coletivo") são atravessados em um contágio. No coletivo que adentra o caminho de casa, o que fica atravessado é o começo de uma vida que menos se parece com uma vida. Poderia ser um natimorto, mas é um bebê ("seu bebê atravessado pelo contágio"). A película de vidro que protege é, porém, perfurada por um "bebê caído/ de uma teta mirrada de mãe verde". No excesso de luz, a "ver/dade" fura, e "ver", apesar de rimar com "fazer", não indica a mesma coisa, pois a "verdade" solapa a rima, assim como o real que fura. O que se filtra do sol é o que se expõe sem filtro: "avanço protegida por uma película/ de vidro - esta janela - por onde/ filtro cegada pelo sol o bebê caído". Retornar à casa é ser atravessada por uma "voz de fantasmas" que está no "coletivo". O "poema solitário" é uma escrita do "coletivo", uma escrita da invisibilidade de uma multidão daqueles e daquelas que, apesar de estarem ao nosso lado, em um coletivo, estão à margem do olhar. Uma escrita da invisibilidade e, também, da inviabilidade, no transporte que se quer como viabilidade. No coletivo, o que transborda é precariedade, é a falta em contraste com o excesso ("aqui sou eu que tenho pele demais").

O retorno à casa, ao lar (com toda a carga simbólica que essa palavra tem, como aconchego, proteção, acolhimento, conforto) é atravessado pela "faixa dos conflitos onde se espera a gratuidade dos extermínios". A saída é atravessada por uma criança "recém-saída/ da faixa dos conflitos onde se espera a gratuidade dos extermínios". A vida recém-saída sai de uma vida sem vida, de uma vivente que, como um fantasma, não está exatamente viva, mas não está morta, está como uma morta-viva, uma vida sem vida. Uma oferta de "algo a mais" é atravessada por um pedido de subtração, o esquecimento ("ela diz me 
dá dinheiro e depois me esqueça"). A tentativa de esquecer é escrita enquanto rasura na permanência da escrita. Em cima da certeza do esquecimento ("vamos te esquecer certamente"), o "breve ensaio" se traça como uma escrita do não esquecimento. No final, uma "herança abraâmica (judaica, cristã, sobretudo cristã, e islâmica)" (DERRIDA, 2008, p. 43): o perdão. Mais precisamente, três pedidos de perdão ("perdoa-nos a pele, perdoa a indiferença dos poetas, as notas nos bolsos") e uma aporia: finca-se a per-duração da memória lá onde se diz de seu esquecimento; no perdão, a doação, o per-doar. O pedido de perdão é precisamente um perjúrio, ele indica o não cumprimento da promessa, a sua traição. É só nessa traição que o perdão será justamente um per-doar, uma perduração. Assim, nessa infidelidade, garante-se a manutenção do perdão, isto é, da recordação. Na promessa não cumprida, no contrato desfeito, traça-se a tentativa de reversibilidade do que já é irreversível, pois, como Derrida diz, "só se tem a perdoar o imperdoável" (DERRIDA, 2008b, p. 44). Todo o poema é um pedido de perdão enquanto recordação, enquanto tentativa de "memória absolutamente viva do inapagável" na contracorrente da certeza do esquecimento (DERRIDA, 2008b, p. 44). Esse perdão, porém, é paradoxal: ele não é só um perdão por não cumprir com pedido de esquecimento, mas um perdão por, todos os dias, cumprir com o pedido de esquecimento ("me esqueça, sei, compreendi mas/ é que não posso é que não sei e é/ exatamente o que faço todos os dias"). Ele é, a um só tempo, um "perdão por não te escutar" e "perdão por, todos os dias, te escutar". ${ }^{4}$ Nesse paradoxo, a escrita dessa promessa cumprida e não cumprida, a escrita sobre e por sobre o esquecimento, se condensa toda no último verso, em apenas um verso, em uma condensação extrema de uma palavra. O último verso, deslocado do restante do poema, separado por um espaço em branco, por um hiato, "dissociado e separado pela duração abissal de um branco de silêncio, como que um aforismo disjunto, a

4 Em A literatura em segredo, sobre a leitura de Kierkegaard do sacrifício de Isaac em Temor e tremor, Derrida diz: "Abraão assim pede perdão por ter estado disposto a fazer o pior sacrifício com o objetivo de cumprir seu dever para com Deus. Ele pede perdão a Deus por ter aceitado fazer o que Deus ele mesmo tinha Ihe ordenado. Perdão, meu Deus, de ter escutado, diz-Ihe em suma. Há aí um paradoxo que nós não deveríamos cessar de pensar. Ele revela em particular uma dupla lei secreta, uma dupla limitação inerente à vocação do perdão. Ela nunca se mostra como tal mas ela sempre deixa ouvir: eu não te peço perdão por ter te traído(a), (...) eu te peço perdão, ao contrário, por ter te escutado(a)" (DERRIDA, tradução inédita de Piero Eyben). 
sentença ou o veredito de um outro tempo" (DERRIDA, 2008a, p. 32). Na economia de um verso, uma réplica do poema todo, "a sentença, a pausa, o último apelo, o dizer ou o ditame, ou mesmo o veredito do poema" (DERRIDA, 2008a, p. 37), a súplica, como uma prece: "fica". Não à toa a "precariedade" deriva de "prece": em O fogo e o relato, Giorgio Agamben nos diz: "'Precário"" significa o que se obtém através de uma prece (AGAMBEN, 2018, p. 33).

No poema de Tatiana Pequeno, endereçar-se a essa precariedade como uma em prece se faz em um deslocamento cujo foco não é a chegada, mas o que fica atravessado. Em outras palavras, o que está em jogo no poema é o que se fica para trás, o que se deixa para trás, o que se perde, enfim, o preço que se paga para realizar a travessia:

não lembro exatamente qual era teu nome
se rodrigo rafael ricardo renato
eu usava um anel para dedos largos
tucum certamente jamais marcassita
vinha de cordovil pela penha (aos treze)
e sabia que no caminho da poesia
haveria de atravessar vielas variadas do subúrbio
e a defloração do corpo era um preço
caro que as mulheres pagam
muito cedo como pedágio para permanecer vivendo
(fiz parte muito tempo do grupo de fêmeas
que desconheciam a diferença entre
romance e estupro)
(PEQUENO, 2019, p. 81)

A citação acima é um trecho do poema intitulado "caixa de joias". Nessa caixa de pandora abre-se a experiência do trauma. Muitos poemas de Onde estão as bombas expõem uma travessia pelas margens que atravessam mundo afora. Atravessar uma violência - que, nesse caso, é uma violência contra as mulheres - não é só atravessar os subúrbios, é atravessar certa história do Brasil e certa história daqueles e daquelas que ficam à margem no mundo. Nessa "caixa de joias", "vão-se os anéis" e fica "uma mão aberta", e o que resta dessa caixa é o "corpo curado no curtume": "onde perdi tudo ficou uma mão aberta/ na porta daquele cômodo mofado/ vão-se os anéis caídos nos bueiros dos subúrbios/ fincam-se os dedos no silêncio/ do corpo curado no curtume" (PEQUENO, 2019, p. 82). 
Podemos dizer que os poemas de Tatiana Pequeno estão sempre a caminho do subúrbio, mesmo quando não estão efetivamente. Isso significa dizer que o destino para onde os poemas acenam é sempre o que fica à margem, um subterrâneo que, na verdade, está exposto na superfície. Há um verso do poema "a cor da pele" que diz: "eu acordo e digo/ tenho mais um dia para contar a história dos subúrbios" (PEQUENO, 2019, p. 72-73). No começo dele, lemos:

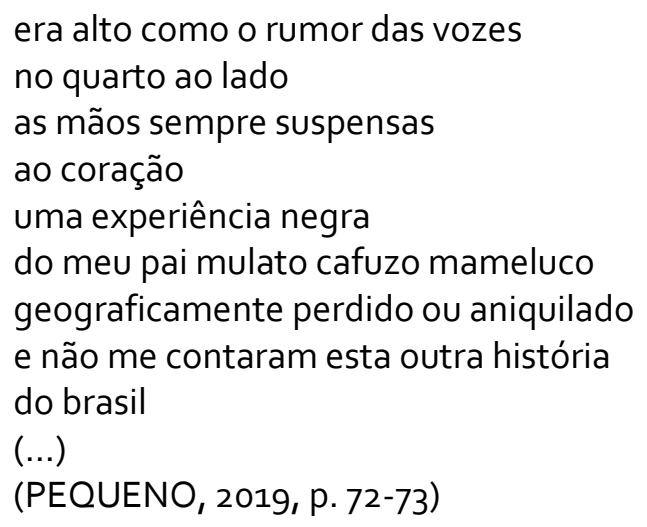

No "rumor das vozes/ no quarto ao lado", uma "outra história/ do brasil", uma história de exclusão, uma "história dos subúrbios". Nas cartas endereçadas à pessoa amada, a linhagem dos marcados pela falta e pela perda. No fogo cruzado da violência, em meio a incontáveis e incomensuráveis danos, uma mulher conta mais um dia, mais um dia ganho para contar a história de perdas e danos. Atravessada pelo que fica interrompido, uma mulher vive para contar a história da violência, da exclusão e da extinção como quem não se esquece do horror em uma carta de amor.

Diante do que foi abordado, vimos que um dos pontos em comum que une parte da produção da poesia brasileira recente escrita por mulheres é a condição precária, é o ponto de precariedade em que as vidas que neles estão em jogo são vidas mais facilmente expostas à morte. Ao longo dos poemas, vimos que essa condição não se dá só pelo gênero, mas, também, pelo fator da pobreza. As poetas expõem as faces dessas condições tematizando a misoginia, o machismo, o feminicídio, o racismo, o colonialismo, os preconceitos de gênero e a pobreza em uma abordagem que entrelaça amor e política, o íntimo e o público. Afinando-se com a noção de "precariedade" ou de "condições 
precárias" em Butler, especialmente com o que ela diz em Corpos em aliança, "uma condição compartilhada de precariedade situa nossa vida política" (BUTLER, 2018, p. 106), esse artigo pretendeu mostrar que essas várias condições de precariedade fazem dessas poetas uma comunidade, uma comunidade cujo modo de amar já situa determinados corpos como corpos mais expostos a riscos, os aproximando em uma luta lá onde eles aparentemente não se aproximariam.

\section{Referências bibliográficas}

AGAMBEN, Giorgio. O fogo e o relato: ensaios sobre criação, escrita, arte e livros. Tradução de Andrea Santurbano e Patricia Peterle. São Paulo: Boitempo, 2018.

ARISTÓTELES. Política. Tradução de Nestor Silveira Chaves. São Paulo: Edipro, 2009 .

BUTLER, Judith. Corpos em aliança e a política das ruas: notas para uma teoria performativa de assembleia. Tradução de Fernanda Siqueira Miguens. Rio de Janeiro: Civilização Brasileira, 2018.

BUTLER, Judith. Vida precária: os poderes do luto e da violência. Tradução de Andreas Lieber. Belo Horizonte: Autêntica Editora, 2019.

DERRIDA, Jacques. Carneiros - o diálogo ininterrupto: entre dois infinitos, o poema. Tradução de Fernanda Bernardo. Coimbra: Palimage, 2008a.

DERRIDA, Jacques; SPIRE, Antoine. Para além das aparências. Leiria: Textiverso, 2008b.

DERRIDA, Jacques. A literatura em segredo: uma filiação impossível. Tradução de Piero Eyben. Inédito.

HOLLANDA, Heloísa Buarque. Explosão Feminista: arte, cultura, política e universidade. São Paulo: Companhia das Letras, 2018. Edição em ebook.

NASCIMENTO, Tatiana. o7 notas sobre o apocalipse ou poemas para o fim do mundo. Rio de Janeiro: Garupa; Kza1, 2019a.

NASCIMENTO, Tatiana. Cuírlombismo literário. Série Pandemia. São Paulo: n-1 edições, 2019b. 
PEQUENO, Tatiana. Aceno. Rio de Janeiro: Oficina Raquel, 2014.

PEQUENO, Tatiana. Onde estão as bombas. Juiz de Fora: Macondo, 2019.

\footnotetext{
' Doutora em Teoria Literária pelo Programa de Pós-Graduação em Ciência da Literatura da Faculdade de Letras da Universidade Federal do Rio de Janeiro. Contato: danielle.h.magalhaes@gmail.com.
} 